\title{
DEVELOPMENT OF RECIPTURES OF CANNED SMOTHIES MADE FROM ZUCCHINI AND FRUITS
}

\author{
Anastasiia Tokar \\ Department of Technology of Storage and Processing of Fruits and Vegetables \\ Uman National University of Horticulture \\ 1 Institutska str., Uman, Ukraine, 20305 \\ anastasi.oleynik@gmail.com \\ Liudmyla Matenchuk \\ Department of Technology of Storage and Processing of Fruits and Vegetables \\ Uman National University of Horticulture \\ 1 Institutska str., Uman, Ukraine, 20305 \\ matenchuk77@gmail.com

\section{Zinaida Kharchenko} \\ Department of Technology of Storage and Processing of Fruits and Vegetables \\ Uman National University of Horticulture \\ 1 Institutska str., Uman, Ukraine, 20305 \\ harchenco1955@gmail.com \\ Iryna Haidai \\ Department of Technology of Storage and Processing of Fruits and Vegetables \\ Uman National University of Horticulture \\ 1 Institutska str., Uman, Ukraine, 20305 \\ gaydayira35@gmail.com
}

\section{Nadiia Zahorko}

Department of Processing and Food Production Equipment named after professor F. Yalpachik Tavria State Agrotechnological University

18 B. Khmelnistskiy ave., Melitopol, Ukraine, 72312

zahorko@ukr.net

Vira Tarasenko

Department of Processing and Food Production Equipment named after professor F. Yalpachik Tavria State Agrotechnological University

18 B. Khmelnistskiy ave., Melitopol, Ukraine, 72312

vera.tarasenko@tsatu.edu.ua

Valentyna Verkholantseva

Department of Processing and Food Production Equipment named after professor F. Yalpachik Tavria State Agrotechnological University

18 B. Khmelnistskiy ave., Melitopol, Ukraine, 72312

valentyna.verkholantseva@gmail.com

\section{Nadiia Palianychka}

Department of Processing and Food Production Equipment named after professor F. Yalpachik Tavria State Agrotechnological University

18 B. Khmelnistskiy ave., Melitopol, Ukraine, 72312

palyanichkan@gmail.com

\section{Inna Povorozniuk}

Department of Chair of Tourism, Hotel and Restaurant Business

Pavlo Tychyna Uman State Pedagogical University

1 Sadova str., Uman, Ukraine, 20300

Inna-173@ukr.net 


\author{
Lesia Kravchenko \\ Department of Techno-Technological Disciplines \\ Labor Protection and Life Safety \\ Pavlo Tychyna Uman State Pedagogical University \\ 1 Sadova str., Uman, Ukraine, 20300 \\ kravchenkolesiav@gmail.com
}

\begin{abstract}
Rational nutrition for a whole year is possible with a well-established system of storage and processing of plant raw materials. Products with vegetable and fruit raw materials due to their availability and nutritional value are in demand among the population. There is a constant interest in new products with increased biological value. The preservation of ascorbic acid, the main source of which is vegetables and fruits, is also affected by the technology of production. Despite the damaging effect of the heat treatment temperature of canned products on thermolabile components, the sterilization regimes should be relaxed. To this end, it has been proposed to produce beverages from vegetables and fruits for scientifically-based recipes, which allows them to be processed at a temperature of $100{ }^{\circ} \mathrm{C}$, as well as juices with pulp and sugar. Smoothie, made on the basis of zucchini with the addition of gooseberries and blackcurrant puree contain respectively 13.3 and $41.8 \mathrm{mg} / 100 \mathrm{~g}$ of ascorbic acid, have an optimal for good perception of the sugar-acid index 21,4-21,5 compared with juices from soft pulp and sugar from gooseberry and black currant, which produces industry. The latter is explained by the fact that instead of sugar syrup, natural juice from zucchini was used in the recipe.
\end{abstract}

Keywords: zucchini, gooseberries, blackcurrants, juices with pulp and sugar, smoothie.

(C) Anastasiia Tokar, Liudmyla Matenchuk, Zinaida Kharchenko, Iryna Haidai, Nadiia Zahorko, Vira Tarasenko, Valentyna Verkholantseva,

\title{
1. Introduction
}

Nutrition significantly affects the health status, working capacity and life expectancy of a person. Therefore, food products for health and prophylactic purposes, enriched with vitamins, essential amino acids, micro- and macro elements, other biologically active substances (BAS) are becoming increasingly popular [1].

Nutrition science refers vegetables to healthy foods because their energy value is low, they supply the human body with biologically active substances, pectins, dietary fibers that participate in the formation of the microbiota of the gastrointestinal tract, enhance its peristalsis, have probiotic properties [2].

A promising area for the creation of functional food products is the creation of beverages using plant materials, in particular - smoothie, which is becoming more popular today. Beverages have not only good organoleptic properties, but a high content of BAS, which makes them useful for human health [3].

The creation of multicomponent products for people of different age groups with a given set of properties is a complex process that requires the most complete balance of products with a large number of components of the chemical composition, therefore, the correct choice of raw materials plays an important role in solving this problem [4].

Zucchini is quite common in Ukraine. Zucchini bourgeons contain sugars, organic acids, a large number of polyphenolic compounds [5]. According to various data, the content of sugars in zucchini varies between $1.4 \ldots 4.6 \mathrm{~g} / 100 \mathrm{~g}[6,7]$. Depending on the variety, the titrated acidity of zucchini is $0.07 \ldots 0.14 \%$, and most of all is contained in isomonic, citric-malic and malic acids [5].

Fruits contain salts of phosphorus, copper, iron, which are important for digestion. Carbohydrates zucchini easily assimilated by the human body, therefore used in children's nutrition, with catarrhs of the stomach, increased acidity and peptic ulcer. Fruits contain $6.0-6.5 \%$ of dry substances, including 3.0-3.5 \% of sugars, 1.0-1.2\% pectin substances. There is no starch in the technical ripeness zucchini. Acidity low - less than $0.1 \%$. The fiber content is not high $(0.2-0.5 \%)$, therefore they have a gentle consistency and good taste qualities [8]. 
The content of dry soluble substances in fruits of gooseberry is $10-15 \%$, the main component of dry soluble substances of gooseberry is sugar, the content of which is $7-13 \%$. The content of organic acids is $1.2-3.0 \%$, vitamin $\mathrm{C}-20-50 \mathrm{mg} / 100 \mathrm{~g}$ [9].

The chemical composition of blackcurrant varies widely, depending on the variety, areas of growth, and agricultural technology. The water content can vary from $74.5 \%$ to $87 \%$, solids from 13 to $26.4 \%$. Sugars are from 5.7 to $13.7 \%$ (glucose predominates). Sorbitol is $0.09-0.33 \%$, the total acidity (in terms of citric acid) is 1.8-4.3\%; all found in berries of varying degrees of ripeness are three organic acids - oxalic, citric and malic. The total amount of pectin substances is $0.83-1.65 \%[10,11]$.

Ascorbic acid is the most common vitamin. It has antioxidant properties, participates in the regulation of carbohydrate metabolism and blood coagulation, promotes tissue regeneration, increases the body's resistance to infections, reduces the need for other vitamins. The daily requirement of an adult in ascorbic acid is $100 \mathrm{mg}$, and for a child 20-60 mg. Deficiency of vitamin $\mathrm{C}$ leads to weakening of the immune system, slowing of tissue regeneration, bleeding gums, loss of teeth, varicose veins, excess weight, increased fatigue, irritation, depression, insomnia, hair loss, blurred vision [12].

The aim of research is development of a recipe for a zucchini, gooseberries and blackcurrants smoothie that will expand the range of vegetable and fruit canned food and rationally use raw materials that are valuable in their chemical composition.

\section{Materials and Methods}

Vegetables and fruits were grown and harvested in experimental areas, processed in the laboratory of the Department of Technology of Storage and Processing of Fruits and Vegetables of the Uman National University of Horticulture, Uman, Ukraine. For research used zucchini of varieties Excellence F1, gooseberry of varieties Source, blackcurrants of varieties Sofievskaia. The quality indicators of the finished products were determined at the Uman National University of Horticulture, Uman, Ukraine, individual in the Taurian State Agrotechnological University, Melitopol, Ukraine, and Uman Pedagogical University, Uman, Ukraine. The canned products were prepared according to the different formulations given in Table $\mathbf{1 .}$

Table 1

Juice recipe, g per $1000 \mathrm{~g}$ ( $\mathrm{kg}$ per $1000 \mathrm{~kg})$

\begin{tabular}{|c|c|c|c|}
\hline \multicolumn{2}{|c|}{ Control variant } & \multicolumn{2}{|c|}{ Projected variant } \\
\hline Juice & Recipe & Canned food & recipe \\
\hline \multirow[t]{3}{*}{$\begin{array}{l}\text { Gooseberry with pulp and } \\
\text { sugar (control) }\end{array}$} & puree -500 & Zucchini-gooseberry smoothies & Zucchini juice -634 \\
\hline & syrup- 500 , & & Gooseberry puree -258 \\
\hline & incl. white sugar -110 & & White sugar - 108 \\
\hline \multirow[t]{3}{*}{$\begin{array}{l}\text { Blackcurrant with pulp and } \\
\text { sugar (control) }\end{array}$} & puree -500 & Zucchini-blackcurrant smoothies & Zucchini juice - 699 \\
\hline & syrup -500 & & Blackcurrant puree - 191 \\
\hline & incl. white sugar -110 & & White sugar - 110 \\
\hline
\end{tabular}

Projected smoothies variants were calculated relying on earlier studies and derived based on their design formulas to ensure active acidity in the finished product is not higher than $3.9 \mathrm{pH}$ units. The canned products were prepared according to different formulations and the mass fraction of titrated acids was determined potentiometrically and active acidity ( $\mathrm{pH}$-meter model MP511), the results were processed using the Microsoft Excel software "Statistica" (2010). 
In fresh raw materials and canned processing products, the mass fraction of dry soluble substances (DSS) according to DSTU ISO 2173:2007 [13] was determined using a laboratory refractometer (Fig. 1), sugars according to DSTU 4954:2008 [14] using a spectrophotometer (Fig. 2), titratable acidity in terms of malic acid according to DSTU 4957:2008 (GOST ISO 750) [15], active acidity according to DSTU 6045: 2008 in units of pH (DSTU ISO 1842) [16] m (Fig. 3), the content of ascorbic acid in accordance with GOST 24556-89 (DSTU ISO 6557-2) [17] using a spectrophotometer (Fig. 2).

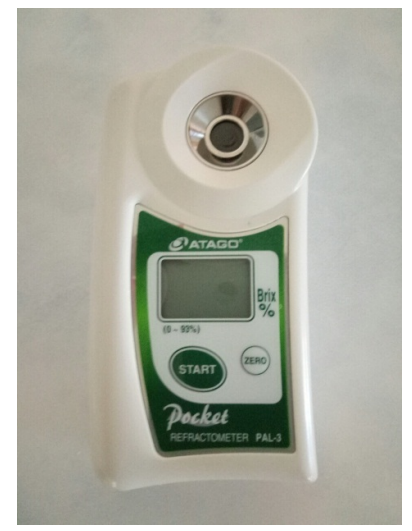

Fig. 1. PAL-3 refractometer (Japan)

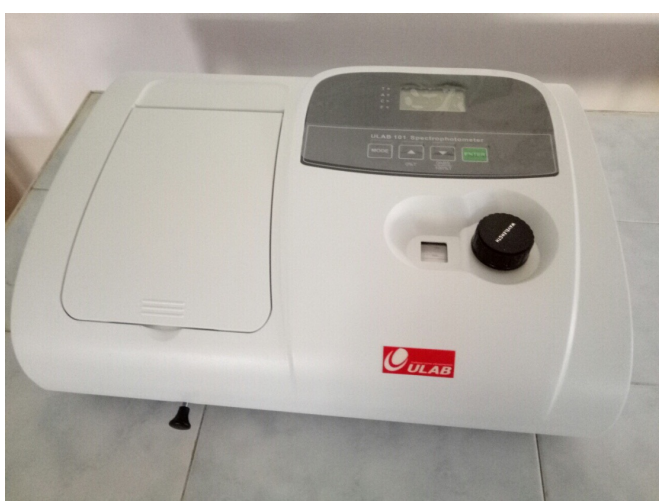

Fig. 2. Ulab 101 spectrophotometer (China)

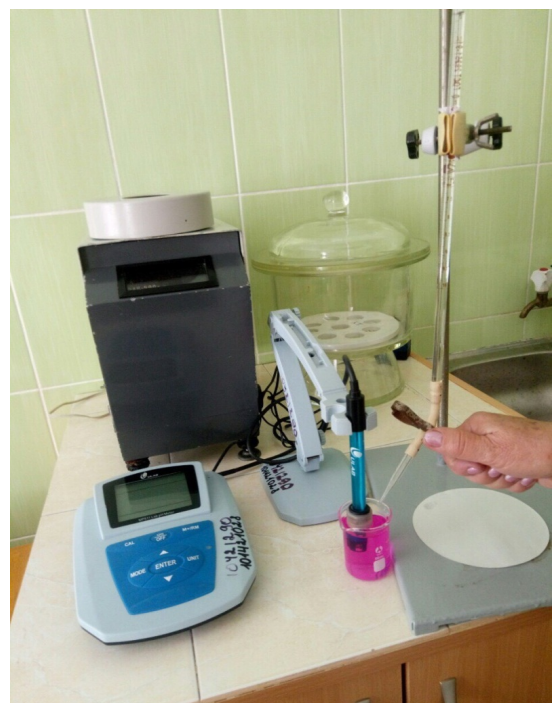

Fig. 3. Laboratory $\mathrm{pH}$ meter, model MP511 


\section{Results}

The regression equation calculated predicted the smoothies quality in which the calculated mass fraction of solids is $16.0 \%$, and the mass fraction of titrated acidity is $0.6 \%$, which should ensure an active acidity level of not more than 3.9 units of $\mathrm{pH}$ and the sterilization temperature is not higher

The carried out researches of the content of some components of the chemical composition indicate that the greatest amount of dry soluble substances (DSS) have accumulated berries of gooseberry and blackcurrants, the smallest content in zucchini, 2.3 times as compared to berries of black currant, gooseberry - 2.7 times (Table 2).

Table 2

The content of some components of the chemical composition of fruits

\begin{tabular}{|c|c|c|c|c|}
\hline \multirow{2}{*}{ Fruit } & \multicolumn{3}{|c|}{ mass fraction, $\%$} & \multirow{2}{*}{$\begin{array}{c}\text { Ascorbic acid content, } \\
\mathrm{mg} / 100 \mathrm{~g}\end{array}$} \\
\hline & dry soluble substances & sugars & titrated acids * & \\
\hline zucchini & 4,4 & 3,4 & 0,05 & 14,0 \\
\hline gooseberry & 12,0 & 8,5 & 2,10 & 32,0 \\
\hline black currant & 10,0 & 8,0 & 2,90 & 213,0 \\
\hline $\mathrm{HIP}_{05}$ & 0,6 & 0,3 & 0,3 & 2,5 \\
\hline
\end{tabular}

It is established that the greatest content of sugars was stored by berries of gooseberry $8.5 \%$, in black currant they are $0.5 \%$ less and 2.5 times less in zucchini. Organic acids are rich in berries of black currant, somewhat less than in berries of gooseberry. In the fruits of zucchini organic acids less in berries of gooseberries -42 times, black currants -58 times. The research results confirm that the berries of black currant are leading in the content of ascorbic acid in comparison with other raw materials, namely, it is contained in blackcurrant 15.2 times more than in fruits of zucchini and 6.5 times more than in berries gooseberries.

Having examined the quality of raw materials chosen for research and processing, it can be concluded that all raw materials are valuable in chemical composition and suitable for the production of new vegetable and fruit canned food.

When designing new types of canned food, the taste and aromatic and physicochemical parameters of the raw materials chosen for research were taken into account. The results of the studies on the determination of the content of the components of the chemical composition of fruit and vegetable-fruit canned food are given in Table 3.

Table 3

Physical and chemical indicators of juices

\begin{tabular}{|c|c|c|c|c|c|}
\hline Canned food & $\begin{array}{c}\text { Dry soluble } \\
\text { substances, \% }\end{array}$ & Sugars, \% & $\begin{array}{c}\text { Titrated acids, } \\
\%\end{array}$ & $\begin{array}{l}\text { Active acidity, } \\
\text { units of pH }\end{array}$ & $\begin{array}{l}\text { Sugar-acid } \\
\text { index }\end{array}$ \\
\hline $\begin{array}{l}\text { Gooseberry juice with pulp and } \\
\text { sugar (control) }\end{array}$ & 16,9 & 13,5 & 1,00 & 3,5 & 13,5 \\
\hline Zucchini and gooseberry smoothies & 15,9 & 12,6 & 0,59 & 3,8 & 21,4 \\
\hline $\mathrm{HIP}_{05}$ & 0,1 & 0,2 & 0,06 & 0,25 & - \\
\hline $\begin{array}{l}\text { Blackcurrant juice with pulp and } \\
\text { sugar (control) }\end{array}$ & 16,6 & 13,3 & 1,4 & 3,2 & 9,5 \\
\hline Zucchini and blackberry smoothies & 15,9 & 12,7 & 0,59 & 3,8 & 21,5 \\
\hline $\mathrm{HIP}_{05}$ & 0,2 & 0,3 & 0,03 & 0,03 & - \\
\hline
\end{tabular}


The carried out researches on definition of a rational parity of the basic components of vegetable-fruit smoothies - fruit raw materials: a gooseberry and a blackcurrant and vegetable zucchini. A basis (a semi-finished product) for smoothies' creation - puree made from gooseberry and black currant is developed. Since the is a thick beverage, in order to create a liquid consistency, juice made from the fruit of the zucchini was included in the recipe.

Formulations of zucchini-fruit smoothies were calculated using formulas that take into account the balance of soluble solids and the content of titrated acids. This ensures the maintenance of the main indicators in the finished product within the limits, normalized by normative and technical documentation for fruit juices with pulp and sugar [18] and most importantly, the $\mathrm{pH}$ of the finished product is guaranteed within optimal limits, which makes it possible to use heat treatment at a temperature of $100^{\circ} \mathrm{C}$.

The content of dry soluble substances in the control variants was dominated by the lard juice with pulp and sugar - by $0.3 \%$ more than in the case of the blackcurrant juice, which is explained by the chemical composition of the raw materials. A similar trend is observed in the content of titrated acids and sugars.

The taste qualities of the finished product are characterized by a sugar-acid index. Calculation of the recipe for new types of canned food guarantees optimal boundaries for this indicator and provides high organoleptic qualities of new types of canned food.

The samples of the fruit and vegetable smoothies studied differed significantly in the content of dry soluble substances, sugars, titrated and active acidity and the sugar and acid index from the same juices with pulp and sugar, which is due to their recipes.

We investigated the content of ascorbic acid in the investigated canned fruit samples - fruit juices taken for control and in the zucchini-fruit smoothies (Fig. 4).

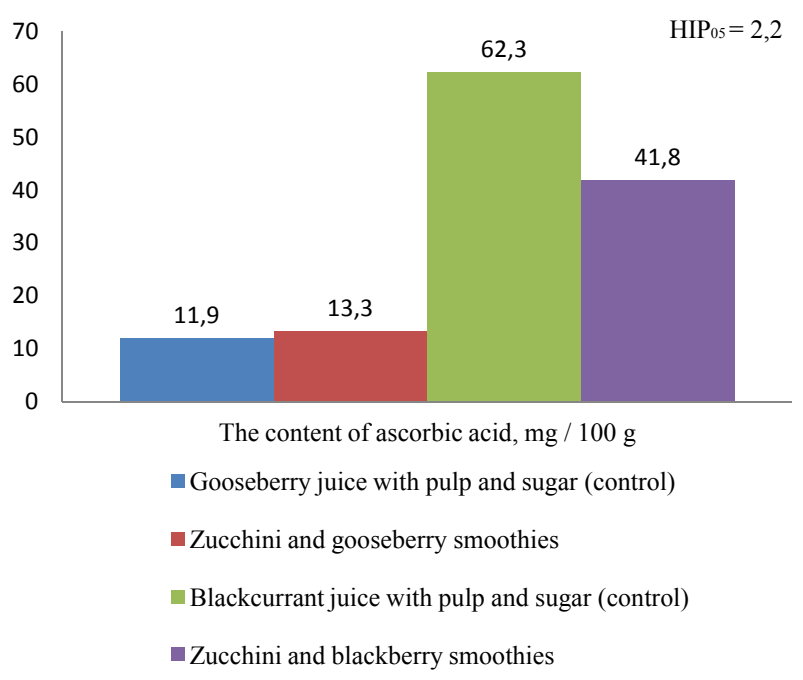

Fig. 4. Mass fraction of ascorbic acid, $\mathrm{mg} / 100 \mathrm{~g}$

The content of ascorbic acid was dominated by samples of canned food based on blackcurrant, which is explained by the high content of this component in raw materials. The control variant of the blackcurrant juice prevailed juice from gooseberry 5.2 times in content of ascorbic acid and 1.5 times compared with the zucchini-blackcurrant smoothies. The zucchini-gooseberry smoothies did not significantly dominate the control variant by $1.4 \mathrm{mg} / 100 \mathrm{~g}$. This difference is explained by the chemical composition of the raw materials and the recipe for canned food.

\section{Conclusions}

1. Popularity and recognition of the new generation drinks with vegetables and fruits smoothies - are gaining popularity. Zucchini are in great demand among the population due to their high taste and nutritional qualities. The preserves, made from zucchini in combination with black currant and gooseberry, contain a large number of active substances, without adding any 
additives. Analysis of the literature confirms the advisability of using the raw materials to expand the assortment of canned food.

2. It is established that blackcurrant berries accumulate $10 \%$ of dry soluble substances, 8.0 - sugars, $2.9 \%$ titrated acids, $213 \mathrm{mg} / 100 \mathrm{~g}$ ascorbic acid, and berries of gooseberry 12.0, 8.5, $2,1,32$. The fruits of zucchini accumulate fewer nutrients than berry raw materials.

3. The combination of highly acidic fruit raw materials and low acidic zucchini is suitable for the production of new beverages, balanced by the content of titrated acidity and the sugar-acid index. The positive result of this research is the expansion of the range of drinks using zucchini, the rational use of valuable raw materials - berries of gooseberry and blackcurrant, coincidence of the maturation of raw materials. After further improvement, the development of sterilization regimes, new beverages deserve introduction to production.

\section{References}

[1] Ukrainets, A. I., Simakhina, H. O. (2009). Tekhnolohiya ozdorovchykh kharchovykh produktiv. Kyiv: NUKhT, 310.

[2] Kutkina, M. N., Kotova, N. P., Eliseeva, S. A. (2016). Sovershenstvovanie tekhnologii universal'nyh ovoshchnyh polufabrikatov dlya predpriyatiy industrii pitaniya. Vestnik VGUIT, 2, 153-157.

[3] Tiurikova, I. S., Peresichnyi, M. I., Rohova, N. V. (2015). Rozroblennia tekhnolohiyi smuzi na osnovi topinambura z vykorystanniam voloskoho horikha. Tekhnologii pishchevoy, legkoy i himicheskoy promyshlennosti, 5 (4), 9-13.

[4] Ferreira, M. P., Gendron, F., Kindscher, K. (2013). Bioactive Prairie Plants and Aging Adults. Bioactive Food as Dietary Interventions for the Aging Population, 263-275. doi: https://doi.org/10.1016/b9780-12-397155-5.00032-5

[5] Iswaldi, I., Gómez-Caravaca, A. M., Lozano-Sánchez, J., Arráez-Román, D., Segura-Carretero, A., Fernández-Gutiérrez, A. (2013). Profiling of phenolic and other polar compounds in zucchini (Cucurbita pepo L.) by reverse-phase high-performance liquid chromatography coupled to quadrupole time-of-flight mass spectrometry. Food Research International, 50 (1), 77-84. doi: https://doi.org/10.1016/j.foodres.2012.09.030

[6] Palma, F., Carvajal, F., Lluch, C., Jamilena, M., Garrido, D. (2014). Changes in carbohydrate content in zucchini fruit (Cucurbita pepo L.) under low temperature stress. Plant Science, 217-218, 78-86. doi: https://doi.org/10.1016/j.plantsci.2013.12.004

[7] Massolo, J. F., Concellón, A., Chaves, A. R., Vicente, A. R. (2013). Use of 1-methylcyclopropene to complement refrigeration and ameliorate chilling injury symptoms in summer squash. CyTA - Journal of Food, 11 (1), 19-26. doi: https://doi.org/10.1080/19476337.2012.676069

[8] Puzik, L. M., Obraztsova, Z. H. (2012). Osoblyvosti formuvannia vrozhainosti kabachka zalezhno vid klimatychnykh umov. Visnyk Poltavskoi derzhavnoi ahrarnoi akademiyi, 1, 30-72.

[9] Yanovskyi, Yu. P., Voievodin, V. V., Chepernatyi, O. M., Lapa, O. M. (2009). Yahidnytstvo. Kyiv, 215.

[10] Asami, D. K., Hong, Y.-J., Barrett, D. M., Mitchell, A. E. (2003). Comparison of the Total Phenolic and Ascorbic Acid Content of Freeze-Dried and Air-Dried Marionberry, Strawberry, and Corn Grown Using Conventional, Organic, and Sustainable Agricultural Practices. Journal of Agricultural and Food Chemistry, 51 (5), 1237-1241. doi: https://doi.org/10.1021/jf020635c

[11] Smorodyna chorna. Available at: http://isykhiya.blogspot.com/2015/04/blog-post_12.html

[12] Dubinina, A. A. (1993). Tekhnologiya polucheniya polufabrikatov iz semechkovyh i kostochkovyh plodov. Kharkiv, 177.

[13] DSTU ISO 2173:2007 (ISO 2173: 2003, IDT). Vyznachennia rozchynnykh sukhykh rechovyn refraktometrychnym metodom. Produkty z fruktiv ta ovochiv (2010). Kyiv: Derzhspozhyvstandart Ukrainy, 7.

[14] DSTU 4954:2008. Metody vyznachennia tsukriv. Produkty pereroblennia fruktiv ta ovochiv (2009). Kyiv: Derzhspozhyvstandart Ukrainy, 17.

[15] DSTU 4957:2008. Metody vyznachennia tytrovanoi kyslotnosti. Produkty pereroblennia fruktiv ta ovochiv (2009). Kyiv: Derzhspozhyvstandart Ukrainy, 10.

[16] DSTU 6045:2008. Metod vyznachannia rN. Frukty, ovochi ta produkty pererobliannia, konservy miasni ta miasoroslynni (2009). Kyiv: Derzhspozhyvstandart Ukrainy, 12.

[17] GOST 24556-89 (SEV 6245-88). Metody opredeleniya vitamina S. Produkty pererabotki plodov i ovoshchey (1989). Moscow: Izd-vo standartov, 16.

[18] GOST 16366-78. Soki plodovye i yagodnye s myakot'yu. Tekhnicheskie usloviya (1979). Moscow: Izd-vo standartov, 12. 